\title{
"ESTAS VOZES PROFERIDAS (...) EM SI SÃO NADA, MAS SÃO SINAIS DE MUITO": MURMURAÇÕES NOS FURORES SERTANEJOS DE 1736 EM MINAS GERAIS*
}

\author{
Tarcísio de Souza Gaspar \\ Mestre em História pela Universidade Federal Fluminense \\ e historiador vinculado à Prefeitura Municipal de Ouro Preto
}

\section{Resumo}

Este artigo investiga as murmurações e vozes orais veiculadas nos Furores Sertanejos de 1736.

\section{Palavras-chave}

revolta $\bullet$ vozes $\bullet$ murmurações.

\section{Abstract}

This article investigates the whisperings and oral voices [murmurings] transmitted in the Backcountry's Riots of 1736.

\section{Keywords}

revolt $\bullet$ voices $\bullet$ murmurings.

Com ligeiras modificações, este artigo é parte de minha dissertação de Mestrado, intitulada Palavras no chão: murmurações e vozes em Minas Gerais no século XVIII, defendida em abril de 2008 junto ao Programa de Pós-Graduação em História da Universidade Federal Fluminense. Agradeço ao professor Guilherme Pereira das Neves, que orientou a realização do trabalho; às professoras Maria Beatriz Nizza da Silva e Laura de Mello e Souza e ao professor Luciano Raposo de Almeida Figueiredo, integrantes da banca avaliadora. Agradeço também à Fundação de Amparo à Pesquisa do Estado do Rio de Janeiro (Faperj), financiadora da pesquisa. 
Este artigo investiga as murmurações e as vozes orais veiculadas nos $\mathrm{Fu}-$ rores Sertanejos, série de revoltas que sacudiu a porção noroeste da Capitania de Minas Gerais em 1736. Objetiva-se problematizar a natureza da opinião pública colonial, enquanto lugar social de conflito, em que se chocam linguagens e interesses políticos divergentes. Avaliando mensagens orais, foi possível recompor enunciados políticos e engrenagens sociais importantes da formação histórica de Minas.

Desde o afã migratório de fins do século XVII, a região mineradora foi palco para mil murmurações e outras tantas histórias veiculadas de boca em boca. $\mathrm{O}$ conteúdo épico do povoamento, a carestia alimentar, as dificuldades da viagem e da sobrevivência logo se juntaram às disputas entre grupos aventureiros. À animosidade de taubateanos e paulistas, seguiram-se as escaramuças com os forasteiros, polemizando o nascedouro das Minas. A Guerra dos Emboabas se deu também, ou principalmente, no campo da boataria. Menos habilidosos no trato com os rumores, os paulistas sofreram desgastes simbólicos que contribuíram para a sua derrota, como afirma Adriana Romeiro. ${ }^{1}$ Depois deste conflito, a introdução de administradores e de funcionários, a montagem do aparelho fiscal e a regulação do cotidiano colonial acirraram as línguas dos moradores. A concentração de riquezas e de recursos humanos, simbólicos e políticos nas mãos de poucos indivíduos constituíram a garganta-raiz deste palavreado. A opinião pública das Minas conformou-se à sociedade que a gerava.

A oralidade impregnou todos os grupos sociais, desde o rico potentado até o mais insignificante escravo, cliente ou vadio. Resultante do analfabetismo e da pouca inserção no universo letrado, a cultura oral refletiu ali a sociedade de Antigo Regime, caracterizada por certa prática política que reservava às murmurações e às linguagens orais um papel fundamental no encaminhamento e na resolução de conflitos. A desigualdade social, enquanto produto de relações ou como norma oficialmente ratificada pela monarquia, deixou sua marca nas comunicações interpessoais e nos burburinhos comunitários, inserindo fissuras na opinião pública local. Pobres e ricos, indivíduos de posições hierárquicas equidistantes tendiam a dialogar linguagens distintas, não obstante as influências

\footnotetext{
ROMEIRO, Adriana. A Guerra dos Emboabas: novas abordagens e interpretações. In: RESENDE, Maria Efigênia Lage de; VILLALTA, L. C. (orgs.). História de Minas Gerais: as Minas setecentistas. Belo Horizonte: Autentica; Companhia Tempo, 2007, p. 529-548, v. 1, p. 544. ROMEIRO, Adriana. Paulistas e Emboabas no coração das Minas: ideias, práticas e imaginário político no século XVIII. Belo Horizontes: EdUFMG, 2008, p. 219-223.
} 
recíprocas. O ponto de contato mais importante na relação entre os sussurros populares e as vozes da elite acontecia quando as murmurações ganhavam difusão em rede, transmitindo-se dos poderosos a agregados e escravos, para enfim, ganhar o ambiente público da sociedade. Próximas, mas distintas, as vozes da gente miúda e dos potentados possuíram conteúdos paradoxais. Ora caminham juntas, ora se repelem.

Neste sentido, quanto à história das Minas, a primeira metade do século XVIII pode ser vista como época em que as vozes inferiores e superiores obtiveram maior proximidade política. Intimadas por problemas comuns e influenciadas pela conjuntura de formação institucional da capitania, as murmurações deste período conjugaram os interesses ambivalentes da "ínfima plebe" e dos “cabeças". Nos variados conflitos que eclodem até 1750, a opinião pública mineira esteve fortemente caracterizada por rumores propagandeados em rede, que obedeciam à lógica clientelar. $\mathrm{O}$ poder dos potentados capacitava-os a influenciar na formulação, na divulgação e na recepção de mensagens públicas, tumultuando o ambiente político conforme as tensões em jogo num determinado momento. Posto que as murmurações se ramificassem, todos os grupos sociais, e não só os integrantes da rede, se tornavam interlocutores do debate.

Esta tipologia de comunicações se fez presente nos embates da década de 1710, na Revolta de Vila Rica (1720) e nos Furores Sertanejos. Constituindo uma perigosa e polêmica comunidade de sujeitos falantes, as vozes proferidas em rede estendiam sua rivalidade para além dos limites do grupo clientelar e atingiam os demais membros da sociedade, arregimentando-os sob uma mesma conversa. Entretanto, isto não implicou que o conjunto de vozes dialogasse uma única linguagem. Existiram camadas discursivas variadas, que podiam conjugar significados políticos e sociais específicos. Nos motins de 1736, alguns interesses de fundo popular mantiveram-se na ponta das línguas rebeldes, e só episodicamente eles coincidiram com as aspirações dos grupos de poderosos que capitanearam as sobreditas desordens. Justapostas e congruentes, as motivações populares puderam se juntar às reivindicações dos potentados; mas o fizeram resguardando para si certo papel autônomo de participação política.

\section{Capitação e Censo de Indústrias: um novo olhar}

Em 1733, veio a lume um novo pacote fazendário direcionado à Capitania de Minas Gerais: o projeto da capitação e censo de indústrias. Escrito e explicado por Alexandre de Gusmão, o plano objetivava reformar as práticas fiscais 
e tributárias da Coroa portuguesa naquele território colonial. Tratava-se de um amplo conjunto normativo, cujo enfoque recaía, especialmente, na contenção dos descaminhos do quinto e na racionalização do sistema de taxas alfandegárias, postas sobre o giro comercial.

O cuidado quanto ao desvio do ouro foi menos enfoque que obsessão. Aparecia mesmo como contundente resposta da Coroa ao problema da sonegação aurífera. Decerto, a era dos contrabandos, instalada na década de 1720, durante o governo de dom Lourenço de Almeida, alertara para o fato de que, se Portugal quisesse extrair o quinto com eficácia, coibindo perdas, o modelo tributário deveria prever não só os movimentos da população, mas também a corrupção burocrática. Alguns artigos do projeto da capitação rogaram explicitamente por uma "forma certa e segura, para que nem aos particulares nem aos ministros" fosse possível "desviar coisa alguma do verdadeiro produto". Além disto, a reforma ainda vangloriava-se por simplificar ao extremo a algazarra fiscal da capitania. Registros, taxas, direitos de passagem, direitos de lavoura, senhoriagem, braçagem, contratos, dízimos, quintos, donativos, subsídios, enfim, toda a sorte de tributos maiores e menores seria abolida, trocados pela mão única da capitação. ${ }^{2}$

O texto tinha como argumento básico a junção entre os interesses metropolitanos e os que se supunham existir do outro lado do Atlântico. A simplicidade fiscal demonstrar-se-ia proveitosa ao príncipe e ao vassalo. Ao monarca, porque a Fazenda Real recolheria maior cabedal; e ao súdito, porque escapava da multiplicidade tributária. Todas as taxas seriam comutadas por duas apenas: 1- matrícula de escravos e 2- maneio e censo de indústrias. Afora isto, correriam livres as transações econômicas, deixando "a cada qual negociar com o ouro na espécie que lhe parecer e introduzir nas Minas ou extrair delas os gêneros que quiser, sem pagar mais direitos que aqueles que já se acha[m] estabelecidos nos portos do mar". ${ }^{3}$

A matrícula de escravos consistia numa taxa geral e única, de 10 oitavas, a ser cobrada sobre cada cativo. Em período determinado, os proprietários deveriam pronunciar todo seu plantel, pagando quota per capita, individualizada, dos escravos em sua posse. O tributo incidiria sobre a totalidade dos senhores e

\footnotetext{
2 Fontes históricas do imposto de capitação. Revista do Arquivo Público Mineiro (RAPM), v. 12, p. 605-676, 1907, p. 609. Grifo meu.

3 Fontes históricas do imposto de capitação. RAPM, v. 12, p. 605-676, 1907, p. 606.
} 
dos cativos, não havendo exceções à regra, nem respeito às distinções de status ou condição. Quanto aos escravos, isto significava que, independentemente de suas ocupações (fossem de ganho, mineradores, comerciantes, trabalhadores domésticos e outros), de suas idades (fossem idosos ou jovens, desde que maiores de 14 anos) e do sexo, seriam eles objeto de quantia idêntica, obedecendo aos mesmos procedimentos. Quanto aos senhores, clérigos, nobres, militares, funcionários, mineradores, agricultores, comerciantes, negociantes, todos pagariam por suas posses, inclusive governadores e demais ministros do rei. ${ }^{4}$

Previram-se penas rigorosas tanto ao atraso no pagamento da matrícula (punido com multa) como à sonegação de escravos, implicando esta na alforria imediata do cativo, além de permanecer a cota do senhor. Os mínimos detalhes foram esmiuçados, desde as formas de lidar com possíveis dúvidas e omissões nas idades dos escravos mais jovens, com cativos enfermos, ou doentes, e até com negros fujões ou comerciados de uma praça para outra. Também existiria fiscalização sobre os próprios funcionários, que poderiam se conluiar para fraude. ${ }^{5} \mathrm{O}$ pagamento da quota gerava um bilhete pessoal e intransferível, válido por um ano, que certificava a legalidade do cativo. Perda, furto ou corrupção do comprovante não haviam de ser tolerados. Escravos que se soubessem sonegados por seus senhores podiam denunciá-los, ganhando, com isto, a liberdade. ${ }^{6}$

A segunda parte do projeto discorria a respeito do maneio e censo de indústrias. Estes, diferentemente da matrícula, visavam incidir sobre os lucros do comércio, da pequena e grande agricultura e dos ofícios, atividades com menor emprego da mão-de-obra escrava. Uma taxa de 5\% seria calculada sobre a renda das casas comerciais e /ou abastecedoras, escalonadas em onze classes de estabelecimento. Detalhe curioso do maneio era a norma de que todas as pessoas livres de Minas, com idade igual ou superior a 18 anos, também devessem pagar imposto proporcional a sua renda, sob um mínimo de 5 oitavas de ouro por ano. ${ }^{7}$ Estariam isentas do censo de indústrias apenas as seguintes pessoas:

4 Fontes históricas do imposto de capitação. RAPM, v. 12, p. 605-676, 1907, p. 616.

Fontes históricas do imposto de capitação. RAPM, v. 12, p. 605-676, 1907.

${ }^{6}$ Fontes históricas do imposto de capitação. RAPM, v. 12, p. 605-676, 1907.

Imaginava-se que, em Minas, cada pessoa livre ganhasse, no mínimo, cem oitavas de ouro por ano. Daí, deduzindo-se o imposto de $5 \%$, chegava-se às cinco oitavas mínimas. O raciocínio era rígido e truculento. Vagabundos, vadios ou pessoas com renda anual inferior a 100 oitavas deveriam suportar o ônus ou migrar para outra capitania da colônia. Em todo caso, pela raridade deste tipo de cálculo, as informações devem ser frisadas, perdoando suas imprecisões. Deduz-se delas que o mais pobre trabalhador de Minas angariasse entre oito e nove oitavas de ouro por 
governador, intendentes, ouvidores, juízes de fora, oficiais da arrecadação, mulheres brancas sob a tutela de marido ou dos pais, eclesiásticos, oficiais de justiça e militares (estes últimos desde que não envolvidos em comércio ou trabalho fora da Igreja, do ministério ou da tropa, respectivamente). Por outro lado, incluir-se-iam nele os letrados, médicos, cirurgiões, boticários e pessoas de profissão semelhante. Filhos maiores de família, ainda não emancipados, pagariam o chão de 5 oitavas. Forros e forras também entravam na conta; ponto importante: independentemente de suas ocupações e rendas, teriam eles de arcar com contribuição mínima de 10 oitavas, mesmo que seus cabedais não atingissem a classe correspondente de 200 oitavas anuais. Na ficha de pagamento do maneio, abria-se brecha, inclusive, à omissão da nomenclatura do ofício, desde que o contribuinte respondesse por seus ganhos - possível artimanha para suavizar a inclusão de prostitutas, alcouces, ladrões ou criminosos. ${ }^{8}$

O documento exarou, aqui e acolá, noções valiosas sobre a economia mineradora, quando, por exemplo, compara a tipologia dos cabedais mineiros à existente no reino. Enquanto Portugal arrendava lucros variados e múltiplos, oriundos de censos, juros, foros, propinas, aluguéis, arrendamentos, os capitais de Minas "se reduzem todos a estas duas espécies, o que se adquire com o trabalho dos negros (...) e o que se ganha com a própria indústria". ${ }^{9} \mathrm{O}$ julgamento relegava a segundo plano os negócios da agiotagem e do empréstimo de dinheiro a juros que, como é sabido, infestavam a colônia, especialmente as Gerais. ${ }^{10}$ Em todo caso, o apreço ganha relevância na medida em que espelha uma determinada visão acerca da economia colonial, reconhecendo-lhe apenas os elementos oficiais e legalmente constituídos, como o abastecimento e a atividade voltada à exportação.

Todavia, a fonte não desmerece de todo a pujança do mercado interno mineiro, uma vez que o próprio projeto de capitação e censo de indústrias espremia ao máximo, e de maneira até então nunca vista, as possibilidades fiscais oferecidas pelos setores médios urbanos da capitania. Taxas per capita sobre os escravos

mês, ou seja, de 12 a $14 \$ 000$ réis. Extraindo-se as cinco oitavas do tributo, a média mensal abaixava para 7,9 oitavas, ou $11 \$ 850$ réis. Fontes históricas do imposto de capitação. RAPM, v. 12, p. 605-676, 1907, p. 628-29.

8 Fontes históricas do imposto de capitação. RAPM, v. 12, p. 605-676, 1907, p. 630-34.

9 Fontes históricas do imposto de capitação. RAPM, v. 12, p. 605-676, 1907, p. 631.

${ }^{10}$ FURTADO, Júnia Ferreira. Homens de negócio: a interiorização da metrópole e do comércio nas Minas setecentistas. São Paulo: Hucitec, 1999. 
não eram novidade. Elas já haviam sido observadas em vários momentos, desde 1714. Mas, antes, não se incluíam cativos de trabalho doméstico, artífices e tampouco aqueles desligados de atividades produtivas. Por outro lado, o maneio, inédito imposto sobre a renda, engolfava toda a população economicamente ativa de Minas, desde o grande negociante até oficiais mecânicos, taverneiros, assalariados, mascates, homens e mulheres, libertos e forros, jovens e idosos, criminosos e meretrizes.

Sob determinado ponto de vista, o censo de indústrias lançou uma aposta sagaz em relação aos proventos comerciais. A alíquota de 5\% sobre o faturamento do mercado, caso levada a efeito rigoroso, poderia angariar quantias inesperadas e de todo imprevisíveis. Alexandre de Gusmão certamente intuíra a rentabilidade dos negócios coloniais, como um ramo econômico já altamente desenvolvido, mas ao qual a Coroa dera até ali pouca importância. Além disso, o mentor do projeto estimava que, depois de algum tempo, seria possível aumentar o percentual de ônus sobre o comércio, igualando-o aos tributos da mineração e dos escravos. Em seu plano, a quota das indústrias só não foi maior devido à "comoção" que se seguiria à primeira cobrança repentina. ${ }^{11}$

Portanto, a capitação e o maneio ajustavam a temperatura do fisco português ao "termômetro" da economia mineira, cujas oscilações obedeciam ao número de escravos e aos lucros do comércio. O modelo tributário mudou, com isto, seu foco de recolhimento, não mais direcionado à produção aurífera e sim ao trabalho e às rendas dos vassalos. ${ }^{12}$ Num só golpe, praticamente extinguia as artimanhas tradicionais de desengano dos quintos e, ao mesmo tempo, taxava a acumulação interna de riquezas, numa curiosa mistura entre pacto colonial e o conhecimento de seus desvios ou "desaguadouros". ${ }^{13}$

${ }^{11}$ Fontes históricas do imposto de capitação. RAPM, v. 12, p. 605-676, 1907, p. 628-29.

12 CAMPOS, Maria Verônica. Governo de mineiros: "de como meter as minas numa moenda e beber-lhe o caldo dourado", 1693 a 1737. São Paulo, 2002. Tese de Doutorado, História, Faculdade de Filosofia, Letras e Ciências Humanas, Universidade de São Paulo, p. 121.

${ }^{13}$ Há menção explícita aos prejuízos decorrentes do tráfico independente entre Brasil e Costa da Mina: “(...) é [preciso] vedar totalmente negócio em direitura do Brasil para a Costa de África, ordenando que se faça somente de Portugal para ela, e daí para o Brasil, donde tornariam os navios para o reino. Não me dilato mais sobre este ponto, pois muitas vezes se tem representado já a Sua Majestade, assim o inconveniente que nasce da navegação do Brasil para a Mina, e mais Costas da Guiné, como o remédio de fazer este negócio por companhia, que é o meio que parece mais seguro, mais proveitoso para o Reino e para a Real Fazenda (...); (...) enquanto estiver aberto de qualquer sorte que seja aquele desaguadouro, serão baldadas todas as diligências e leis que se fizessem para proibir o levar-se o ouro em pó aos estrangeiros, que na dita 
Porém, o projeto possuía pontos de sensibilidade e polêmica. O primeiro deles advinha do fato de incidir sobre o trabalho e não sobre a produção. Um mineiro com muitos escravos podia extrair quantidade ínfima de ouro, pagando tributo oneroso, ao passo que outro, com poucos cativos, garimparia riqueza, sem dispêndio fiscal. Mais um impasse originava-se da abrangência demasiada das matrículas. Sendo taxada a totalidade dos escravos, o peso recaía também sobre setores alheios à mineração, como a agricultura, o pastoreio e, inclusive, os serviços urbanos - já que até cativos domésticos ou artífices não estariam isentos.

No início de 1734, chegava ao Brasil Martinho de Mendonça de Pina e de Proença, pequeno fidalgo da Casa Real envolvido nos serviços do rei e que fora por este incumbido da missão de encabeçar mudança no sistema dos quintos, além de outras iniciativas. ${ }^{14} \mathrm{O}$ enviado trazia regimento específico, determinando-lhe suas margens de ação. A tarefa ingrata espelhou-se em recomendações cuidadosas que alertavam para o perigo à vista. A reorientação fazendária devia ser discutida em junta local, com os procuradores das câmaras e mais homens do costume, de molde a ratificar, por via legal, todas as medidas aventadas. Importava, sobretudo, "tratar o negócio de maneira que o desejo dos mesmos povos justifique toda a resolução que se tomar". Escusavam-se constrangimentos e sugestões, que fariam menos legítimo o "ânimo" do pleito. A extrema cautela e a necessidade de anuência dos povos emprestavam à provisão um conteúdo liberal que despertaria inveja aos futuros "cantores da marselhesa". ${ }^{15}$

Costa negociam; e sendo tão consideráveis, como se sabe, as somas que por aquelas veredas se desencaminham, virão sempre a causar grande desfalque no lucro da moeda que a Fazenda Real poderia fazer sobre toda a importância delas." Fontes históricas do imposto de capitação. $R A P M$, v. 12, p. 605-676, 1907, p. 646. Para um apanhado sobre o comércio transatlântico entre Brasil e Costa da Mina, veja-se FRAGOSO, João; GOUVÊA, Maria de Fátima. Nas rotas da governação portuguesa: Rio de Janeiro e Costa da Mina, séculos XVII e XVIII. In: FRAGOSO, João et alii (org.). Nas rotas do Império: eixos mercantis, tráfico e relações sociais no mundo português. Vitória: Edufes; Lisboa: IICT, 2006, p. 25-72.

${ }^{14}$ CAVALCANTI, Irenilda. Foi Vossa Majestade servido mandar: representações e práticas do bom governo nas cartas administrativas de Martinho de Mendonça; Minas Gerais, 1736-37. Rio de Janeiro, 2004. Dissertação de Mestrado, História, Universidade Federal do Rio de Janeiro.

${ }^{15}$ Diogo de Vasconcelos, ao comentar este regimento, escreveu pérola da historiografia: "Dificilmente se encontrará nos anais do regime absolutista uma peça, que tão de molde se entalhe no frontispício dos governos representativos. El-Rei D. João V, se fosse julgado isoladamente por este documento, seria capaz de servir de figura a seus augustos colegas constitucionais. Tributos, com efeito, pedidos e livremente votados pelos povos realizaram o ideal, a que não têm pretendido atingir os mesmos revolucionários cantores da marselhesa." VASCONCELOS, Diogo de. História média de Minas Gerais. Belo Horizonte: Itatiaia, 1974, p. 75. Regm. $t^{\circ}$ ou instrucção que trouxe o governador Martinho de Mendonça de Pina e de Proença. RAPM, v. 3, p. 85-88, 1898, p. 86. 
Uma primeira junta de procuradores, convocada entre 20 e 24 de março de 1734 , rejeitou peremptoriamente a nova proposta. ${ }^{16}$ Criara-se, naquele momento, conjuntura de expectativa e suspense; estavam sendo devassados os crimes de contrabando de diamantes e falsificação de moedas, na máfia organizada durante e pelo governo dom Lourenço de Almeida. ${ }^{17}$ Da mesma forma, expurgava-se o pessoal administrativo e burocrático, caído em suspeita depois da onda fraudulenta. Em julho, Eugênio Freire de Andrade, intendente da Casa de Fundição, um dos maiores implicados, foi finalmente removido do posto. ${ }^{18}$ Por fim, pairavam no ar receios quanto ao Serro do Frio, região envolta sob as névoas vindouras de uma transformação radical. ${ }^{19}$

Ardilosamente, os quintos de 1734 atingiram recorde de contribuição, nunca mais ultrapassado até a extinção da colônia. $\mathrm{O}$ acordo formulado na junta de março, que rejeitara a capitação e maneio, estipulou a cobrança por uma cota de 100 arrobas, acrescida do que se pagasse às Casas de Fundição. Por este método ajuntaram-se nada mais nada menos que 180 arrobas de ouro, entre março de 1734 e julho de 1735 . Influíam no inchaço do bolo fermentos melindrosos, como o receio das devassas, prisões e a maior vigilância sobre os ovos dourados da extração. ${ }^{20}$ Mas, em 1735, a Coroa insistiu na capitação. Em janeiro, a chegada

${ }^{16}$ [Papel acerca dos danos da capitação e de proposta de arrecadação do real quinto do ouro por contrato]. Códice Costa Matoso. Coleção das notícias dos primeiros descobrimentos das minas na América que fez o doutor Caetano da Costa Matoso sendo ouvidor-geral das do Ouro Preto, de que tomou posse em fevereiro de 1749 , \& vários papéis. Coordenação geral de Luciano Raposo de Almeida Figueiredo e Maria Verônica Campos. Belo Horizonte: Fundação João Pinheiro, Centro de Estudos Históricos e Culturais, 1999, v. 1, p. 439-442.

${ }^{17}$ Documentos diversos - fábrica de pólvora de Villa Rica. RAPM, v. 3, 1898, p. 779-781.

${ }^{18}$ AHU. Decreto de dom João V para que Eugênio Freire de Andrade se recolha para o reino e que João da Costa de Matos, provedor da Casa da Moeda do Rio de Janeiro ocupe o lugar de superintendente das Casas de Fundição das Minas, vencendo o ordenado com que foi criado o dito cargo. Lisboa, 18 de julho de 1734. Documentos manuscritos avulsos da Capitania de Minas Gerais, caixa 27, documento 9.

${ }^{19}$ Regm. $\mathrm{t}^{\mathrm{o}}$ ou instrucção que trouxe o governador Martinho de Mendonça de Pina e de Proença. RAPM, v. 3, 1898, p. 85-88. CAVALCANTI, Irenilda. Foi Vossa Majestade servido mandar: representações e práticas do bom governo nas cartas administrativas de Martinho de Mendonça; Minas Gerais, 1736-37. Rio de Janeiro, 2004. Dissertação de Mestrado, História, Universidade Federal do Rio de Janeiro.

${ }^{20}$ [Papel acerca dos danos da capitação e de proposta de arrecadação do real quinto do ouro por contrato]. Códice Costa Matoso. Coleção das notícias dos primeiros descobrimentos das minas na América que fez o doutor Caetano da Costa Matoso sendo ouvidor-geral das do Ouro Preto, de que tomou posse em fevereiro de 1749 , \& vários papéis. Coordenação geral de Luciano Raposo de Almeida Figueiredo e Maria Verônica Campos. Belo Horizonte: Fundação João Pinheiro, Centro de Estudos Históricos e Culturais, 1999, v. 1, p. 444. 
dos bilhetes e livros contábeis necessários ao método "deram muito que falar a este Povo". Martinho de Mendonça temia que o burburinho fizesse diminuir o recolhimento do quinto, pois "aqui tudo se governa por quimeras". ${ }^{21}$ Gomes Freire de Andrade foi levado também à frente de Minas Gerais, acumulando-a ao governo da Capitania do Rio de Janeiro, ao qual se vinculara desde 1733. Tomou posse do novo encargo a 26 de março e três meses depois presidia junta deliberativa da mudança fiscal. Um pleito polêmico e controverso conseguiu aprovar a capitação, todavia, sob regulamento bastante diverso do plano original. A matrícula, anteriormente exclusiva aos escravos, foi estendida a todos os forros e homens brancos economicamente ativos, porém, com taxa diminuída de 10 para 4,75 oitavas per capita. O maneio e censo de indústrias sofreu simplificação: lojas grandes pagariam 24 oitavas; medíocres, vendas e cortes, 16 oitavas; inferiores, 8 oitavas; e mascates, 4 oitavas de ouro anuais. ${ }^{22}$

Sem dúvida, a metamorfose dos termos evidencia que o maior incômodo da capitação, o seu verdadeiro pomo de discórdia junto aos vassalos de Minas, não eram as imposições sobre os escravos e, sim, a tributação da riqueza localmente acumulada. Se o abatimento das matrículas chegou a $52,5 \%$, a queda nas alíquotas sobre o comércio e "indústrias" extravasava $84 \%$ de perda, no caso dos estabelecimentos mais rentáveis. ${ }^{23}$ Este detalhe foi pouco enfatizado pela historiografia, que preferiu fixar a capitação e o censo como paliativos para conter o descaminho do quinto. ${ }^{24}$ Outro indício ainda corrobora a influência do

${ }^{21}$ ANTT. Carta de Martinho de Mendonça de Pina e de Proença. Vila Rica, $1^{\circ}$ de janeiro de 1735. Arquivo Nacional da Torre do Tombo. Manuscritos do Brasil, livro 3, fl. 52-52v.

22 [Papel acerca dos danos da capitação e de proposta de arrecadação do real quinto do ouro por contrato]. Códice Costa Matoso. Coleção das notícias dos primeiros descobrimentos das minas na América que fez o doutor Caetano da Costa Matoso sendo ouvidor-geral das do Ouro Preto, de que tomou posse em fevereiro de 1749 , \& vários papéis. Coordenação geral de Luciano Raposo de Almeida Figueiredo e Maria Verônica Campos. Belo Horizonte: Fundação João Pinheiro, Centro de Estudos Históricos e Culturais, 1999, v. 1, p. 445.

${ }^{23} \mathrm{O}$ projeto original do maneio discriminava os empreendimentos comerciais em onze níveis progressivos de lucratividade, com teto de 3.000 oitavas anuais. Deduzindo-se $5 \%$ de imposto, a Coroa levaria dos negócios mais rentáveis 150 oitavas de ouro. Com as modificações, recolheria só 24. Saíram verdadeiramente prejudicados pelo novo ajuste apenas os comércios e mercados mais humildes, que antes pagariam 5 oitavas, e agora arcariam com 8 oitavas. Fontes históricas do imposto de capitação. RAPM, v. 12, p. 605-676, 1907.

${ }^{24}$ Diogo de Vasconcelos também frisou os abatimentos em relação ao projeto original, mas não deu maior importância às cotas do censo. VASCONCELOS, Diogo. História média de Minas Gerais. Belo Horizonte: Itatiaia, 1974, p. 92. Para Maria Verônica Campos, a capitação era sistema rigoroso e repleto de equívocos jurídicos. Sua imposição sobre o comércio deveria apenas compensar as perdas advindas da sonegação aurífera. CAMPOS, Maria Verônica. Governo 
grande comércio nas modificações do projeto. Os contratos de arremate das entradas, das passagens e dos dízimos, que no plano primitivo seriam revogados, não mais o foram. Como se sabe, o arrendamento de tributos constituía empresa de vulto para os negociantes coloniais. ${ }^{25}$ Martinho de Mendonça informou a Gomes Freire as discussões que se faziam a respeito do tributo, parecendo aos mineiros que o comércio saíra "muito aliviado" da concordata. ${ }^{26}$

Aos trancos e barrancos, a capitação e o censo passaram a valer para o ano consecutivo de 1736. Falou-se que o clima policialesco gerado em Minas depois das chegadas de Martinho de Mendonça e do governador Gomes Freire de Andrade contribuíra para silenciar vozes opositoras. As duas autoridades davam prosseguimento à perseguição dos moedeiros falsos. Teriam espalhado "conversas" afirmativas de que os homens de negócios de Minas estavam "perdidos e arruinados por se acharem todos incursos no descaminho do ouro e fábrica de moeda falsa”. Mas a repressão incidira também sobre muitos inocentes, que foram vexados, presos e maltratados. As queixas fixaram-se, sobretudo, no despotismo de Martinho, que teria mantido em regime de cárcere privado pessoas pobres, torturando-as. Um escravo, aprisionado na casa do funcionário, em vista dos insistentes maus tratos, cometera suicídio. Um homem branco, também flagelado, morreu dias após deixar a masmorra residencial. Uma "mulher-dama"

de mineiros: "de como meter as minas numa moenda e beber-lhe o caldo dourado", 1693 a 1737. São Paulo, 2002. Tese de Doutorado, História, Faculdade de Filosofia, Letras e Ciências Humanas, Universidade de São Paulo, p. 336. Destoa desta linha a interpretação de Luciano Raposo de Almeida Figueiredo para quem a capitação "parecia combinar o desestímulo à fraude com uma cobrança socialmente equilibrada com justiça distributiva. (...) O quinto passava a ser encargo de todos os grupos econômicos, não exclusivamente recaindo sobre o minerador." FIGUEIREDO, Luciano. Revoltas, fiscalidade e identidade colonial na América portuguesa: Rio de Janeiro, Bahia e Minas Gerais, 1640-1761. São Paulo, 1996. Tese de Doutorado, História, Faculdade de Filosofia, Letras e Ciências Humanas, Universidade de São Paulo, p. 138-39. Concordo com a visão do autor, embora com a ressalva de que a capitação aceita pela junta de 1735 distinguia-se do projeto original, em termos de justiça distributiva. O sistema implantado diminuía o peso da cobrança sobre os ricos mineradores e comerciantes, ao passo que deixava praticamente intatas as alíquotas sobre roceiros, homens livres pobres e trabalhadores urbanos. Entretanto, forros e libertos tiveram, efetivamente, alívio fiscal (de 10 para 4,75 oitavas per capita), porque acompanharam o decréscimo das taxas sobre os escravos.

${ }^{25}$ SAMPAIO, Antônio Carlos Jucá de. Os homens de negócio do Rio de Janeiro e a sua atuação nos quadros do Império Português. In: FRAGOSO, João et alii (orgs.). O Antigo Regime nos trópicos. A dinâmica imperial portuguesa (séculos XVI-XVIII). Rio de Janeiro: Civilização Brasileira, 2001, p. 74-105.

${ }^{26}$ ANTT. Carta de Martinho de Mendonça de Pina e de Proença a Gomes Freire de Andrade. 28 de junho de 1736. Manuscritos do Brasil, livro 3, fl. 104-106. 
sofrera interrogatório até se enforcar; outro casal foi violentado dentro de seu próprio lar e a esposa, "de dia", quase apanhara "com um bastão". ${ }^{27}$ Difundiase publicamente o "grave medo" quanto às sentenças de morte, "tormento do corpo e prisão", além de confiscos e degredos. ${ }^{28}$

As histórias veiculadas sobre o acordo da capitação e sobre a violência oficial, empregada para consegui-lo, lembram a ritualística de maledicências a respeito das autoridades coloniais. Gomes Freire, o governador, e Martinho de Mendonça, futuro interino, tiveram suas atitudes julgadas na ladainha pública, atenta às iniquidades dos generais. Chama a atenção fossem pessoas de origem humilde aquelas supliciadas pelo burocrata. Entravam em jogo representações estereotipadas do mau governante: despótico, injusto, mentiroso e cruel, punindo vassalos inocentes e esquecendo os culpados; tudo para inculcar terror na consecução de seus objetivos. Ademais, não era, de fato, infundada a tese de que o aceite da capitação só fora alcançado mediante pressões e ameaças. Ao que tudo indica, os dois funcionários souberam utilizar-se dos crimes precedentes para atemorizar largos setores da sociedade mineira, que estiveram envolvidos nas falcatruas até a raiz dos cabelos. Os agentes instrumentalizaram as ameaças, tomando o cuidado de manifestá-las publicamente, não só através de "conversas" que semearam, mas também explicitando ao máximo os atos de punição. Um dos relatos sobre o período enfatizou o detalhe de que os presos eram carregados "pelas ruas" e "postos em ferros", isto é, de molde a despertar reparo nos transeuntes e moradores. ${ }^{29}$

${ }^{27}$ [Papel feito acerca de como se estabeleceu a capitação nas Minas Gerais e em que se mostra ser mais útil o quintar-se o ouro, porque assim só paga o que o deve]. Códice Costa Matoso. Coleção das notícias dos primeiros descobrimentos das minas na América que fez o doutor Caetano da Costa Matoso sendo ouvidor-geral das do Ouro Preto, de que tomou posse em fevereiro de 1749 , \& vários papéis. Coordenação geral de Luciano Raposo de Almeida Figueiredo e Maria Verônica Campos. Belo Horizonte: Fundação João Pinheiro, Centro de Estudos Históricos e Culturais, 1999, v. 1, p. 475-76.

${ }^{28}$ [Papel acerca dos danos da capitação e de proposta de arrecadação do real quinto do ouro por contrato]. Códice Costa Matoso. Coleção das notícias dos primeiros descobrimentos das minas na América que fez o doutor Caetano da Costa Matoso sendo ouvidor-geral das do Ouro Preto, de que tomou posse em fevereiro de 1749 , \& vários papéis. Coordenação geral de Luciano Raposo de Almeida Figueiredo e Maria Verônica Campos. Belo Horizonte: Fundação João Pinheiro, Centro de Estudos Históricos e Culturais, 1999, v. 1, p. 446.

29 [Papel feito acerca de como se estabeleceu a capitação nas Minas Gerais e em que se mostra ser mais útil o quintar-se o ouro, porque assim só paga o que o deve]. Códice Costa Matoso. Coleção das notícias dos primeiros descobrimentos das minas na América que fez o doutor Caetano da Costa Matoso sendo ouvidor-geral das do Ouro Preto, de que tomou posse em fevereiro de 1749, \& vários papéis. Coordenação geral de Luciano Raposo de Almeida Figueiredo e Maria 
Seja como for, mesmo admitindo-se que, no centro de Minas, os artifícios oficiais tenham abafado os murmúrios de rejeição, isto não se deu em todos os lugares da capitania. A certa altura de seu projeto, quando justificava por que até mesmo os escravos domésticos deveriam pagar a matrícula, suprimindo desta feita as possíveis brechas que se abririam à sonegação, Alexandre de Gusmão fez um comentário profético. Seu oráculo intuíra: "sobretudo nos sertões, seria motivo para mil inquietações". ${ }^{30}$

\section{Vozes sertanejas}

Entre julho e agosto de 1735, matrícula alguma foi anotada pelos habitantes da porção noroeste de Minas, às margens dos rios São Francisco e das Velhas. No fim do ano, a mesma lacuna aconteceu. Em fevereiro de 1736, dirige-se à região o intendente André Moreira de Carvalho, comissionado por Martinho de Mendonça de Pina e de Proença, então lugar-tenente de Gomes Freire de Andrade no governo das Minas. O intendente detinha prerrogativas para cobrar a capitação no local. Escusou levar grande escolta, merecendo antes "as armas da prudência que as militares para convencer os ânimos daqueles moradores". ${ }^{31} \mathrm{Em}$ março, já a caminho do sertão, sondou as conversas dos sertanejos, alcançando estarem "sem nenhum ânimo de pagar capitação, uns por rebeldes, outros por desmazelados, outros por totalmente o não terem”. Existiam também vozes publicadas pelos "sequazes" de alguns "cabeçudos", a propagar "errôneas doutrinas", duvidando que os poderosos satisfizessem o tributo. ${ }^{32}$

Enquanto o intendente empreendia viagem, estoura motim no arraial de Capela das Almas, justificado pela ojeriza dos moradores à presença de um juiz ordinário da Vila de Papagaio, que para lá se dirigira a fim de proceder devassa. A desordem formara-se de vadios, que "não queriam que se tirasse devassa aonde nunca se tirou nem se cobrasse direito algum Real aonde só se devia dízimo a Deus". Para o governador interino, a assuada tivera fomento oculto do coronel Antônio Tinoco de Barcelos, suposto mandatário dos 100 vadios armados, e

Verônica Campos. Belo Horizonte: Fundação João Pinheiro, Centro de Estudos Históricos e Culturais, 1999, v. 1, p. 475-76.

${ }^{30}$ Fontes históricas do imposto de capitação. RAPM, v. 12, p. 605-676, 1907, p. 610-611.

${ }^{31}$ ANTT. Carta de André Moreira de Carvalho para Martinho de Mendonça de Pina e de Proença. Sabará, 26 de janeiro de 1736. Manuscritos do Brasil, livro 1, fl. 185.

32 ANTT. Carta de André Moreira de Carvalho para Martinho de Mendonça de Pina e de Proença. Riacho Fundo 18 de março de 1736. Manuscritos do Brasil, livro 1, fl. 191-193v. 
um dos poderosos da Barra do Rio de Velhas. Este primeiro tumulto preparava o terreno para a onda de conflitos que se seguiria. ${ }^{33}$

Em fins de maio, André Moreira de Carvalho pernoitava em Monte Claros, à margem do rio Verde, quando foi cercado por "grande patrulha de gente armada". Os amotinados, por "parte de Deus e El-rei”, rogavam impedir a passagem do intendente, advertindo-lhe que seu prosseguimento "seria com risco de vida". Na manhã seguinte, voltaram ao sítio, para reafirmar o aviso. No dia 3 de junho, o funcionário publicou edital solicitando aos capitães de milícias investigassem quem eram os mascarados da antevéspera. ${ }^{34}$ Depois deste motim, Martinho de Mendonça resolve incrementar suas forças no sertão. Incumbe Francisco da Cunha Lobo e João Soares Tavares, intendentes do Serro do Frio e do Rio das Velhas, respectivamente, de abrir devassa dos crimes sucedidos. Os dois deveriam ser apoiados por tropas militares, capitaneadas pelo mestre-de-campo João Ferreira Tavares de Gouveia, pelo desembargador Francisco da Cunha Lobo e por Pedro Leolino Mariz. ${ }^{35} \mathrm{O}$ interino prevenia-se contra o costume local. Embora a capitação estivesse obtendo sucesso nas principais vilas da capitania, uma reviravolta de coisas ainda era possível, quando os "povos das Minas muitas vezes temem mais quimeras fantásticas, que realidades verdadeiras". ${ }^{36}$

A 19 de junho, o juiz de São Romão, Francisco de Souza Ferreira, enviou ao interino um extenso relato sobre a penúria econômica do sertão. Os moradores mantinham-se exclusivamente da criação de gado vacum e cavalar, faltando-lhes farinha e tudo o mais; eram assombrados por assaltos do gentio bárbaro, que volta e meia assassinava seus escravos e bois; para se prevenirem, os sertanistas andavam armados "ainda em suas próprias casas e o não ser assim receberiam maior prejuízo, e mal passariam estes moradores de mantimentos se não fossem essas minas gerais e seus contornos". O juiz pedia relaxamento da capitação, avisando que a chegada de militares já ocasionara debando de alguns moradores e a venda dos escravos. ${ }^{37}$ No dia 20, Pedro Leolino Mariz, da Vila de Senhora

\footnotetext{
${ }_{33}$ Motins do sertão. RAPM, v. 1, p. 649-672, 1896, p. 649-50.

${ }^{34}$ ANTT. Edital de André Moreira de Carvalho ordenando prisão dos amotinados. Fazenda de São José, 3 de junho de 1736. Manuscritos do Brasil, livro 10, fl. 7-7v.

${ }^{35}$ CAMPOS, Maria Verônica. Governo de mineiros: "de como meter as minas numa moenda e beber-lhe o caldo dourado", 1693 a 1737. São Paulo, 2002. Tese de Doutorado, História, Faculdade de Filosofia, Letras e Ciências Humanas, Universidade de São Paulo, p. 347.

${ }^{36}$ ANTT. Carta de Martinho de Mendonça de Pina e de Proença a Gomes Freire de Andrade. Vila Rica, 6 de junho de 1736. Manuscritos do Brasil, livro 3, fl. 95.

${ }^{37}$ ANTT. Carta de Francisco de Souza Ferreira a Martinho de Mendonça de Pina e de Proença.
} 
do Bom Sucesso, informava Martinho a respeito do constrangimento imposto ao intendente André Moreira em Montes Claros. A movimentação daquele povo não era coisa positiva, pois ali habitava "gente de muito ruim bafo, que sem falar se faz entender". O pequeno regimento de Dragões, constituído de 20 militares, não seria páreo à renitência dos moradores. ${ }^{38}$

Exalam-se os primeiros "bafos" sertanejos. A notícia da vinda de forças militares chega aos currais e, com ela, o boato de prisão de Manuel Rodrigues Soares, potentado do São Francisco e figura lendária das Minas, integrante da velha-guarda rebelde. O mestre-de-campo João Ferreira Tavares de Gouveia comunica o fato ao governador em carta de 24 de junho, estranhando o disparate do vozerio e imputando-o às sugestões de outros poderosos, que desejavam alijar o velho poderoso do sertão. ${ }^{39} \mathrm{O}$ mesmo militar, alguns dias depois, recolhera novidades aos caminheiros, que o alertaram para o motim contra André Moreira de Carvalho, conduzido por 80 "vadios, mulatos, bastardos, carijós e negros forros". Além disso, os fazendeiros diziam que a cobrança da capitação faria desertar gente para a Bahia. ${ }^{40}$ Em vista da expedição militar, unida aos contingentes do desembargador Francisco da Cunha Lobo, nenhum proprietário estava disposto a mostrar "a cara". Todavia, poderiam ainda servir-se de seus "peralvilhos" para executar "alguma das suas". Reinava nos poderosos "o espírito da Revolução e desobediência", e eles não queriam pagar o que deviam ao rei. ${ }^{41}$

A partir de 24 de junho, uma nova revolta ocorre no Brejo do Salgado. No calor das festividades de São João, o motim congregou muita gente armada. Os rebeldes permanecem no arraial até o início de julho e depois migram para São Romão. No dia 6, um "troço de gente sertaneja" procurou o juiz ordinário local para despachar requerimento ao governador da capitania. Os integrantes reconheciam-se como moradores dos sertões do São Francisco e desejavam que o juiz ouvisse e ratificasse suas reivindicações. Argumentaram que, junto a seus antepassados, eles haviam descoberto e povoado o sertão "à custa de seu

São Romão, 19 de junho de 1736. Manuscritos do Brasil, livro 10, fl. 24-25.

${ }^{38}$ ANTT. Carta de Pedro Leolino Mariz a Martinho de Mendonça de Pina e de Proença. Vila de N. S. do Bonsucesso, 20 de junho de 1736. Manuscritos do Brasil, livro 10, fl. 26-27.

${ }^{39}$ ANTT. Carta de João Ferreira Tavares de Gouveia a Martinho de Mendonça de Pina e de Proença. Vila Real, 24 de junho de 1736. Manuscritos do Brasil, livro 1, fl. 5-6v.

${ }^{40}$ ANTT. Carta de João Ferreira Tavares de Gouveia a Martinho de Mendonça de Pina e de Proença. Lapa, 28 de junho de 1736. Manuscritos do Brasil, livro 1, fl. 7-7v.

${ }^{41}$ ANTT. Carta de João Ferreira Tavares de Gouveia a Martinho de Mendonça de Pina e de Proença. Tejuco, 7 de julho de 1736. Manuscritos do Brasil, livro 1, fl. 8-9v. 
sangue e fazendas conquistando dele o gentio bravo". Há mais de quarenta anos defendiam-se, sozinhos, dos ataques indígenas, perdendo vidas e propriedades. Dedicavam-se exclusivamente ao pastoreio "para sustentação das minas". Pelos gados, já pagavam os dízimos, as contagens e os direitos dos registros, taxas que, somadas, remetiam grande cabedal à fazenda do rei. Agora, pressionados a contribuir na capitação, não aceitavam serem incluídos no fisco do quinto, pois não lavravam ouro nem tampouco viviam sobre terras minerais. Ao capitãogeneral das Minas, rogavam o alívio da tributação. O grupo, enfim, saudou a ocasião, colocando-se de pé e gritando em uma só voz: "viva El Rei de Portugal Dom João o quinto, e todos os seus vassalos". ${ }^{42}$

Este requerimento oficial coincide com grande movimentação popular. Das redondezas de São Romão, avançam grupos amotinados, tumultuando o arraial. Cerca de duzentas pessoas armadas tratam de eleger postos e publicar editais "de manifesta rebelião". ${ }^{43}$ Nenhum homem branco participara do alvoroço. Um mameluco é empossado mestre-de-campo dos sublevados. ${ }^{44}$ Pelas ruas de São Romão, a turba entoa brado de "vivas do Povo e morram traidores". Depois da algazarra, os amotinados põem-se em bebedeira, embriagando-se por "muita força de aguardente". ${ }^{45} \mathrm{O}$ motim foi controlado por Domingos Álvares Ferreira, através de "voz de El Rei". Apurou-se que o padre Antônio Mendes Santiago "fora quem ditava as formais palavras do termo sedicioso no motim". Outro religioso, frei Arcângelo, que estava a dizer missa no momento em que a revolta se dispersava, exortou "a que todos seguissem os amotinados, e estranhando os circunstantes as mortes, roubos e incêndios, respondeu que as sublevações eram para bem comum, pois por meio delas se conseguirá o intento". ${ }^{46} \mathrm{O}$ frei reprovara a ação pacificadora de Domingos Álvares Ferreira. Este e seus homens, a partir daí considerados "traidores do povo", foram perseguidos pelos vadios do sertão. ${ }^{47}$

\footnotetext{
${ }^{42}$ ANTT. Requerimento dos moradores do sertão do São Francisco ao general Gomes Freire, redigido e registrado pelo tabelião do distrito de São Romão, Alexandre de Castro Rodrigues. São Romão, 6 de julho de 1736. Manuscritos do Brasil, livro 10, fl. 38-39.

${ }^{43}$ Motins do sertão. RAPM, v. 1, p. 649-672, 1896, p. 650.

${ }^{44}$ ANTT. Carta de Martinho de Mendonça de Pina e de Proença a Gomes Freire de Andrade. Vila Rica, 23 de julho de 1736. Manuscritos do Brasil, livro 3, fl. 131.

45 ANTT. Proposta e requerimento que fazem os povos das minas gerais, e os seus distritos a el-rei nosso senhor que deus guarde. Manuscritos do Brasil, livro 10, fl. 204-209.

${ }^{46}$ ANTT. Carta de Martinho de Mendonça de Pina e de Proença a Gomes Freire de Andrade. Vila Rica, 12 de dezembro de 1736. Manuscritos do Brasil, livro 3, fl. 210-213.

${ }^{47}$ ANTT. Carta de Domingos Álvares Ferreira a Martinho de Mendonça de Pina e de Proença. Acari, 9 de setembro de 1736. Manuscritos do Brasil, livro 10, fl. 84-85.
} 
A 9 de julho, o desembargador Francisco da Cunha Lobo previa vitória fácil sobre os sertanejos amotinados, uma "turba irregular e desordenada", além de serem "réus de traição", o que lhes dificultava o recebimento de auxílio. ${ }^{48}$ O recolhimento da capitação pôde ser empreendido em algumas paragens, o que causou uma ilusória sensação de sossego. Nestes locais, a presença militar coagira os poderosos, como "trovoadas sem raios que assustasse mais que ofendesse" ${ }^{49}$ Entretanto, as devassas de investigação nada conseguiam apurar das desordens passadas e Martinho de Mendonça desconfia de seus prepostos no sertão.$^{50} \mathrm{O}$ governador acreditava que a hostilidade contra a capitação havia sido "influída nos humildes, pelos mais poderosos e principais moradores do sertão". ${ }^{51}$

Mas, a investida contra os rebeldes tornou-se cada vez mais difícil. Os militares reclamam das intempéries e da paisagem agreste do sertão. Pastos secos e ruins não podiam alimentar a cavalaria; "o grande rigor do sol" fazia adoecer os soldados; quando a chuva amenizava, surgiam "malignas" de um aguaceiro diluviano; os rios transbordavam, impedindo a passagem dos viajantes. ${ }^{52}$ Junto a isto, existiam notícias aterrorizantes. Os funcionários recebiam novidades "fantásticas" a respeito das forças amotinadas. O comissário André Moreira de Carvalho a "cada hora [sonhava] novo exército de levantados". ${ }^{53} \mathrm{O}$ mestre-decampo João Ferreira Tavares de Gouveia e o desembargador Francisco da Cunha Lobo, estando ambos nas imediações de São Romão, fugiram dali por conta do boato de que Domingos do Prado, poderoso do sertão, arregimentava cerca de 500 índios flecheiros e mais "inumerável povo", para resistir à chegada das

\footnotetext{
${ }^{48}$ ANTT. Carta de Francisco da Cunha Lobo ao governador. Arraial da Tiririca, 9 de julho de 1736. Manuscritos do Brasil, livro 13, sem folha.

49 ANTT. Carta de Martinho de Mendonça de Pina e de Proença a Gomes Freire de Andrade. Vila Rica, 24 de julho de 1736. Manuscritos do Brasil, livro 3, fl. 133.

${ }^{50}$ ANTT. Carta de Martinho de Mendonça de Pina e de Proença a Gomes Freire de Andrade. Vila Rica, 28 de julho de 1736. Manuscritos do Brasil, livro 3, fl. 135.

${ }^{51}$ ANTT. Carta de Francisco da Cunha Lobo a Martinho de Mendonça de Pina e de Proença. Sítio do Leitão, 19 de julho de 1736. Manuscritos do Brasil, livro 13, sem folha.

${ }^{52}$ ANTT. Carta de João Ferreira Tavares de Gouveia a Martinho de Mendonça de Pina e de Proença. Tiririca Abaixo da Tábua, 29 de julho de 1736. ANTT. Manuscritos do Brasil, livro 1, fl. 16-17v. Carta de João Ferreira Tavares de Gouveia a Martinho de Mendonça de Pina e de Proença. 16 de agosto de 1736. Manuscritos do Brasil, livro 1, fl. 18-19v.

${ }^{53}$ Carta do governador a Gomes Freire de Andrade de 13 de agosto de 1736. APM, SC 55, fl. 100-101v. Documento citado por ANASTASIA, Carla. Vassalos rebeldes: violência coletiva nas Minas na primeira metade do século XVIII. Belo Horizonte: Ed. C/ Arte, 1998, p. 76.
} 
tropas. Segundo Martinho de Mendonça, as vozes eram "quimeras" veiculadas no fito de desestabilizar o governo. ${ }^{54}$

A 6 de agosto, vem à tona a mais violenta e radical tormenta do sertão. A revolta começa no Brejo do Salgado e rapidamente avança até São Romão, passando por localidades como Januário Cardoso e Carunhanha. Os rebeldes obrigam os moradores a engrossar o corpo do movimento; praticam violências, destroem propriedades, assaltam residências. Num dos arrastões, feito em engenho do padre Domingos de Sousa, os rebeldes forçam o irmão do religioso a carregar feixes de lenha para o incêndio da propriedade. Como este começasse a chorar, os incendiários ameaçam-no de morte caso não mudasse o semblante: "logo o pobre homem fez ao mesmo tempo figura de Demócrito e Heráclito, rindo com a boca e chorando com os olhos por não ser vítima cruenta daquelas feras". Cometeram-se abusos sexuais contra escravas e mulheres forras, estupradas à vista de todos. A um moço de São Paulo, que fazia comércio com Goiás, obrigaram que dissesse "viva o Povo"; como o rapaz negasse a saudação rebelde, retorquindo, altivo, com um "viva El-Rei”, foi alvejado de tiro e "persuadindo-o os amotinados terceira e quarta vez para que dissesse viva o povo sempre respondeu constante viva el rei, até que o mataram com três tiros, e algumas facadas acabando mártir pelo seu Rei”. A lista de atrocidades não foi nada edificante. Assassinatos, estupros, matança de animais, execuções sumárias e covardia: toda violência extravasou-se brutalmente..$^{55}$

\footnotetext{
${ }^{54}$ ANTT. Carta de Martinho de Mendonça de Pina e de Proença ao vice-rei conde das Galveias. Vila Rica 26 de setembro de 1736. Manuscritos do Brasil, livro 3, fl. 184-187.

55 ANTT. Relação dos roubos e incêndios e mais insultos que os amotinados praticaram nas suas sublevações, redigida por André Moreira de Carvalho. Manuscritos do Brasil, livro 1, fl. 280284. Este documento arrola os casos de destruição e violência deflagrados durante a revolta. Baseado nele, o historiador Luciano Raposo de Almeida Figueiredo analisou detidamente a simbologia e os temas subjacentes à violência rebelde. Interpretou-os em função da ritualística de insubordinação, recorrente nos motins do Antigo Regime. Mas, matizou algumas características do ambiente sertanejo, a formular práticas específicas de mobilização social e de violência rebelde. FIGUEIREDO, Luciano. Furores sertanejos na América portuguesa: rebelião e cultura política no sertão do rio São Francisco, Minas Gerais - 1736. Revista Oceanos, n. 40 "Fronteiras do Brasil Colonial". Lisboa: Comissão Nacional para as Comemorações dos Descobrimentos Portugueses, dezembro de 1999, p. 128-144; FIGUEIREDO, Luciano. Revoltas, fiscalidade e identidade colonial na América portuguesa: Rio de Janeiro, Bahia e Minas Gerais, 1640-1761. São Paulo: FFLCH/ USP, 1996. Tese de Doutorado, p. 132-190. Embora não remetam especificamente aos Furores Sertanejos, alguns trabalhos recentes, de autorias diversas, voltaram à temática da violência nas Minas. Carla Anastasia interpretou a violência sertaneja como endêmica na região do São Francisco, paragem com precária institucionalização política, agravada pelas constantes quebras de acomodação política entre súditos e governo
} 
Se, em alguns casos, impressiona a gratuidade do morticínio, em outros, os alvos de ataque demonstram certa premeditação lógica. Os amotinados atacam as propriedades de Domingos Álvares Ferreira porque este aplacara o motim de julho. O padre Domingos de Sousa era tido por "traidor do povo", suspeito de manter comunicações ocultas com o governador. Um tabelião teve a casa assaltada por ser parente do "espia”. O saque generalizado a São Romão justificou-se pelo fato de os moradores locais consentirem a permanência de soldados da repressão. ${ }^{56}$

No decorrer do mês de agosto, corre o boato de que o furor planejava irradiarse pelas Minas, chegando até os principais núcleos da mineração. Este vozerio ocasionou muitos cuidados e receios. Propagavam-se notícias exageradas sobre a proporção dos acontecimentos. Temia-se a viagem dos amotinados até Vila Rica, para pedir perdão do crime. Agregando toda gente que encontrasse pelo caminho, a expedição rebelde prometia multidão extraordinária, verdadeira "fúria popular ou infernal", como coisa "nunca vista a permanência e contumácia de um monstro sem ordem nem obediência". ${ }^{57}$ Mas, os rumores nunca

metropolitano. ANASTASIA, Carla. Um exercício de autossubversão: rebeldes facinorosos na sedição de 1736. In: RESENDE, Maria Efigênia Lage de; VILLALTA, Luiz Carlos (orgs.). História de Minas Gerais: as Minas setecentistas. Belo Horizonte: Autentica; Companhia Tempo, 2007, v. 1, p. 567-584; p. 568-69. Já para Celia Nonata da Silva, o fenômeno da violência sertaneja deveu-se à importância cultural de valores privados, como honra, valentia, bravura e desafio, que desembocavam no emprego da força bruta, principalmente no campo e nas lonjuras fronteiriças. As atrocidades se davam devido às disputas entre bandos de poderosos que, armando escravos e agregados, deflagravam, contra bandos opositores, vinganças ou rinhas pessoais, na busca ou manutenção de “territórios de mando". Ressalve-se, entretanto, a fluidez conceitual de algumas classificações centrais empregadas pela autora, tais como "ethos barroco de subversão", "cultura política mestiça" ou "cultura política sertaneja". SILVA, Celia Nonata da. Homens valentes: delimitação dos "territórios de mando" nas Minas setecentistas. Vária História, 2001, n. 24, p. 75-89; SILVA, Célia Nonata da. Autoridade mestiça: Territórios de mando no sertão do São Francisco. Revista Brasileira de História \& Ciências Sociais, v. 1, n. 2, 2009. Enfim, a melhor síntese dos mecanismos de coação física e simbólica presentes nas regiões fronteiriças de Minas está no novo trabalho de Adriana Romeiro. Dialogando com as obras de Carla Anastasia e de Celia Nonata da Silva, a autora concede ênfase à constituição matricial dos núcleos ou polos privados de poder, caracterizados por redes clientelares e por "territórios de mando" orbitados em torno de potentados e poderosos. Romeiro entende este mecanismo como fenômeno fundamental, estruturante mesmo, da sociedade e da colonização mineira, independentemente da maior ou menor presença do Estado metropolitano. ROMEIRO, Adriana Paulistas e Emboabas no coração das Minas: ideias, práticas e imaginário político no século XVIII. Belo Horizontes: EdUFMG, 2008, p. 83-90.

${ }^{56}$ ANTT. Relação dos roubos e incêndios e mais insultos que os amotinados praticaram nas suas sublevações, redigida por André Moreira de Carvalho. Manuscritos do Brasil, livro 1, fl. 280-284.

${ }^{57}$ ANTT. Carta de João Ferreira Tavares de Gouveia ao desembargador Rafael Pires Pardinho. 
se confirmavam e não se sabia ao certo "se isto é realidade ou fábula e balela, dos milhões delas, falsas, que por toda a parte correm". ${ }^{58}$

De qualquer forma, os boatos especulativos causaram confusão no pessoal administrativo. Há disputa entre os funcionários, que se cobram da covardia por eles sentida. O intendente André Moreira de Carvalho acusa a desonra com que se portavam o desembargador e o mestre-de-campo, advertindo-lhes "que as diligências del Rei se deviam fazer com sossego, e não como quem ia ao quintal do vigário de São Romão a furtar laranjas, que, feita a rapina, fugia”. O medo grassava nos soldados e estes, quando conversavam com os outros, "até a língua se lhe fazia branca". No sertão, de nada adiantavam os "cavalinhos de frisa" e "mais instrumentos militares", quando a guerra pedia ação de ataque a "um quilombo de negros". ${ }^{5}$

Também nas Minas, o murmúrio da invasão rebelde seguiu seu curso. Martinho de Mendonça temia a divulgação das vozes, "que podem fazer pernicioso efeito no vulgo". ${ }^{60}$ A covardia dos militares já estava na boca do povo, que zombava publicamente dos soldados, como "a mais vergonhosa ação que se tem visto no país". ${ }^{61}$ Paulatinamente, formou-se clima de incrível expectativa, como um terreno movediço de boatos, oscilando a cada notícia. Houve reparo constante na opinião pública dos vassalos, constituindo uma cultura do pânico que, por sua vez, alimentava a força verbal da revolta. O burburinho punha "em grande risco a quietação e sossego das Minas", ameaçando alastrar o tumulto tal qual palavras se difundiam nas conversações. ${ }^{62}$

Para saber dos boatos e dos movimentos, o lugar-tenente espalhou espias e confidentes por todas as partes da capitania, com exceção do Rio das Mortes, de Mato Dentro e do Ribeirão do Carmo, por serem locais de confiança. Mas, ao mesmo tempo em que vigiou, o interino era também espionado em Vila

Riacho Fundo, 24 de agosto de 1736. Manuscritos do Brasil, livro 1, fl. 34-35.

${ }^{58}$ ANTT. Carta de João Ferreira Tavares de Gouveia a Martinho de Mendonça de Pina e de Proença. Pedras de Amolar, 27 de agosto de 1736. Manuscritos do Brasil, livro 1, fl. 37.

${ }^{59}$ ANTT. Carta de André Moreira de Carvalho a Martinho de Mendonça de Pina e de Proença. Sítio das Almas, 6 de agosto de 1736. Manuscritos do Brasil, livro 10, fl. 49-52v.

${ }^{60}$ ANTT. Carta de Martinho de Mendonça de Pina e de Proença a Gomes Freire de Andrade. Vila Rica, 5 de setembro de 1736. Manuscritos do Brasil, livro 3, fl. 170.

${ }^{61}$ ANTT. Carta de Martinho de Mendonça de Pina e de Proença a Gomes Freire de Andrade. Vila Rica, 12 de setembro de 1736. Manuscritos do Brasil, livro 3, fl. 175.

${ }^{62}$ ANTT. Carta de Martinho de Mendonça de Pina e de Proença a Gomes Freire de Andrade. Vila Rica, 21 de setembro de 1736. Manuscritos do Brasil, livro 3, fl. 179. 
Rica, não faltando quem lhe observasse o "semblante" ${ }^{63}$ Ramificada dentro e fora das Minas, a rede de notícias e murmúrios percorria a colônia. O boato de que dois mil sertanejos avançavam rumo às Gerais teve grande difusão e "não causou pequena impressão, que chegou ao Rio de Janeiro, e se participaria a toda a América, e ao Reino". A 2 de setembro, circula que os rebeldes estariam prestes a atacar Sabará. Desconfiado da veracidade da informação, Martinho tenta desmentir o boato, no intuito "de dissipar o terror pânico que infundiam os avisos falsos, que do sertão se participavam, porque os tinha verdadeiros, e participados com grande velocidade". De fato, o episódio não ultrapassara uma pequena "quadrilha de ladrões, ciganos e mamelucos", que "com voz do Povo" cometera alguns roubos na Barra do Rio das Velhas.

Os acontecimentos da revolta e, principalmente, a composição social dos levantes deixavam dúvida no ar. À frente dos motins, se perfilaram grupos populares, vadios, mamelucos, ciganos, tapuias. Mas, em contrapartida, suspeita-se participação oculta dos grandes do sertão. Em fins de setembro, Martinho de Mendonça ainda mostrava indecisão quanto ao caráter dos Furores Sertanejos, afirmando não ter "juízo seguro". Posto que mamelucos, vadios e pescadores não possuíssem motivos de ojeriza à capitação, pois careciam de escravos, era de supor-se, segundo raciocínio do fidalgo, "que houve quem ocultamente os instigasse, e quem procurasse espalhar quiméricos boatos de levante para intimidar o governo, a ver se conseguia que desistisse da execução”. Novamente, repetia-se aqui um argumento já conhecido: "cabeças" poderosas influíam e controlavam o surgimento das murmurações.

A situação era mais complexa do que parecia. O noroeste mineiro formava região cuja pujança econômica crescia vertiginosamente, depois do povoamento de Goiás e Tocantins. A criação e engorda de gados e o atravessamento de mercadorias angariavam grandes cabedais aos proprietários de terras e aos recolhedores dos dízimos. No entanto, mesmo a pecuária, principal atividade do lugar, empregava pouca mão-de-obra escrava, fazendo, portanto, duvidosa a ideia de que a capitação prejudicasse os criadores. ${ }^{64}$

Urgia, pois, a pergunta: se os escravos eram insignificantes no sertão, por que o tributo fazia-se tão odioso aos proprietários e à gente pobre do lugar? Para o

\footnotetext{
${ }^{63}$ ANTT. Carta de Martinho de Mendonça de Pina e de Proença a Gomes Freire de Andrade. Vila Rica, 21 de setembro de 1736. Manuscritos do Brasil, livro 3, fl. 181.

${ }^{64}$ ANTT. Carta de Martinho de Mendonça de Pina e de Proença ao Conde das Galveias. Vila Rica, 26 de setembro de 1736. Manuscritos do Brasil, livro 3, fl. 184-187.
} 
governador de Minas, a resistência dos poderosos à capitação advinha da perda que os mesmos sofreriam caso a Coroa passasse a controlar o recolhimento de proventos fiscais, até ali tutelados pelos latifundiários da região. ${ }^{65}$ Esta interpretação pode ser aproximada às diferentes conclusões da historiografia. Carla Anastasia enxergou nos motins um contexto de soberania fragmentada, no qual os potentados sertanejos renhiam sujeitar-se à autoridade real, defendendo suas autonomias locais e recusando a concorrência de outro polo de poder ${ }^{66}$ Para Maria Verônica Campos, havia no sertão uma latente disputa envolvendo dois grupos ou duas redes distintas de potentados, que labutavam entre si o controle das rotas e dos lucros comerciais do interior colonial; os levantes sertanejos teriam sido resultantes deste conflito de interesses. ${ }^{67}$ Já Luciano Raposo de Almeida Figueiredo enfatizou a mescla de insatisfações ligadas à capitação, unindo poderosos e populares em uma mesma luta contra o fisco, embora suas posições diferissem política e economicamente. ${ }^{68}$

Tudo leva a crer que os Furores Sertanejos congregassem de fato, e não só na aparência, os interesses de pobres e ricos. Quanto aos poderosos, embora as informações sejam ainda vacilantes e imprecisas, teve relevância a pauta política cujo conteúdo rememorava o antigo conceito (de ascendência paulista) ${ }^{69}$ de um contrato entre súditos e rei: os primeiros sentiam seus direitos violados pela Coroa e, por isto, protestavam. Este argumento foi particularmente evidente no

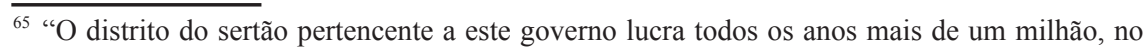
aumento do preço dos gados que nele se engordam, e também dos que se criam que pela conta dos dizimeiros; passam de vinte mil as rezes que nele nascem governando-se as fazendas com pouquíssimos escravos, e não só este ouro mas o produto dos gados do Piauí, e mais sertões, e de muitas carregações desse Porto passava por quintar às mãos dos mais poderosos, e a falta deste ilícito lucro é que lhe faz odiosa a capitação mais que até (ilegível) contribuição que pagam, outros também estranham, por lhes diminuir a liberdade de se servirem com escravos alheios não só que ali se refugiam, mas que induzem aos passageiros." ANTT. Carta de Martinho de Mendonça de Pina e de Proença ao conde das Galveias. Vila Rica, 26 de setembro de 1736. Manuscritos do Brasil, livro 3, fl. 184-187.

${ }^{66}$ ANASTASIA, Carla. Vassalos rebeldes: violência coletiva nas Minas na primeira metade do século XVIII. Belo Horizonte: Ed. C/ Arte, 1998, p. 78.

${ }^{67}$ CAMPOS, Maria Verônica. Governo de mineiros: "de como meter as minas numa moenda e beber-lhe o caldo dourado”, 1693 a 1737. São Paulo, 2002. Tese de Doutorado, História, Faculdade de Filosofia, Letras e Ciências Humanas, Universidade de São Paulo, p. 352-53.

${ }^{68}$ FIGUEIREDO, Luciano. Revoltas, fiscalidade e identidade colonial na América portuguesa: Rio de Janeiro, Bahia e Minas Gerais, 1640-1761. São Paulo, 1996. Tese de Doutorado, História, Faculdade de Filosofia, Letras e Ciências Humanas, Universidade de São Paulo, p. 153-54.

${ }^{69}$ ROMEIRO, Adriana. Paulistas e Emboabas no coração das Minas: ideias, práticas e imaginário político no século XVIII. Belo Horizonte: Ed. UFMG, 2008, p. 274. 
termo rebelde, lavrado pelo juiz ordinário de São Romão, a 6 de julho de 1736. Por outro lado, os grandes do sertão envolviam-se em disputas internas de poder, que perpassavam o controle da economia local, em franco desenvolvimento. $\mathrm{O}$ noroeste mineiro, abrindo uma nova frente de colonização rumo ao centro-oeste da América portuguesa, atraiu diferentes grupos de interesses e, isto, certamente, influenciou no surgimento e no andamento da revolta. Não por acaso, durante os motins, vários poderosos foram alvos da violência rebelde. É possível captar nas entrelinhas as fissuras que separavam alguns sujeitos da alta hierarquia sertaneja. Igualmente, ficam subentendidas as relações que estes grupos de potentados mantinham com outras regiões e instituições da América e do Império Português. ${ }^{70}$

Por seu lado, a massa empobrecida do sertão participou ativa e publicamente dos motins. Já se disse que a capitação onerava os negros forros, classificando-os conforme sua antiga condição de cativos. Mas, é possível estender ainda mais o alcance social do tributo. Como se sabe, entravam na lista fiscal todos os vassalos que exercessem atividades econômicas, e não só os escravos. Havia, inclusive, recomendação especial quanto aos indivíduos impossibilitados de saldar o imposto: vadios, vagabundos, desclassificados, mendigos ou miseráveis deveriam ser expulsos da capitania. Em 1736, muitos foram extraditados para a Colônia de Sacramento. ${ }^{71}$ No ano seguinte, no arraial de Mato Dentro, comarca do Tejuco, fugiram à chegada do intendente responsável pela cobrança da capitação. Desprovidos de meios para pagar suas quotas, eles preferiam se esconder nos matos, "tais como os ciganos", ameaçados de "exterminação" pelo governo. $^{72}$ Talvez, daí se possa entender porque os motins do sertão tiveram vadios, mamelucos, ciganos e vagabundos na linha de frente das rebeliões.

Isto não significa que tais grupos de desclassificados e de mestiços agissem por conta própria ou que estivessem alheios ao círculo de dependências clientelares, característico das sociedades de Antigo Regime. ${ }^{73}$ Os Furores Sertanejos

\footnotetext{
${ }^{70}$ ANTT. Carta de Martinho de Mendonça de Pina e de Proença a Gomes Freire de Andrade. Vila Rica, 12 de dezembro de 1736. Manuscritos do Brasil, livro 3, fl. 210-213v.

${ }^{71}$ ANTT. Carta do intendente da fazenda Francisco de Castro Costa ao governador. São João del-Rei, 10 de fevereiro de 1736. Manuscritos do Brasil, livro 14, sem folha.

${ }^{72}$ ANTT. Carta de Plácido de A. Matoso, intendente da fazenda, ao governador. Arraial do Tejuco, 11 de julho de 1737. Manuscritos do Brasil, livro 13, sem folha.

${ }^{73}$ Para ilustrar esta informação, cito um caso de perseguição aos vadios na vila de São João del-Rei, por conta da capitação, em que um grupo foi retido e "prenderam grande número de pessoas de sorte que quem teve padrinho foi solto, e quem não teve foi no tronco". ANTT. Carta do intendente da fazenda Francisco de Castro Costa ao governador. São João del-Rei, 10 de fevereiro de 1736. Manuscritos do Brasil, livro 14, sem folha. Grifo meu.
} 
obedeceram à lógica de mobilização política tantas vezes utilizada nos motins mineiros da primeira metade do século XVIII. Os poderosos agiam por detrás das cortinas rebeldes, instigando suas massas de agregados e de clientes a deflagrarem ações armadas. Não obstante, no sertão, alguns detalhes apresentavam diferenças ao que ocorria nas vilas do ouro. Às margens do São Francisco, não eram escravos e sim ameríndios e mulatos os agentes diretos do conflito. Ali, a tipologia das redes clientelares pode ter assumido conotações específicas, distintas em relação aos principais núcleos da mineração. Chama a atenção fossem pessoas livres, ainda que de baixa condição, as integrantes das clientelas sertanejas. ${ }^{74}$

E a revolta explorou os interesses ambivalentes da população. Os amotinados publicaram convocatória, argumentando que "toda a casta de gente" deveria oporse à capitação. "Senhores moradores e assistentes, e passageiros, assim brancos como mulatos, e mulatas, e negras e negros forros", todos eram conclamados a pegarem de suas armas, "para defendermos a que se não paguem quintos por ser bem comum". Era preciso evitar a tirania do governador, "para que não nos cavalgue o Sr. Martinho de Mendonça; como tem cavalgado as Minas". Eles se autorreconheciam como "gente de todas as cores" e, por isto, necessitavam de união. ${ }^{75}$

Entretanto, mesmo com discursos de identidade, o furor estaca depois de um grande deslocamento. Arregimentando adeptos no extremo norte de Minas, os rebeldes retornam ao Brejo do Salgado e a São Romão. Mas, nesta empreita, ocorrem fissuras internas, que malquistam entre si as duas autoridades da revolta, o general mulato e mestre-de-campo mameluco. Este é assassinado por seus comparsas. Após o racha, o movimento perde força. O último suspiro acontece quando os grandes do sertão abandonam o barco sublevado. Naufrágio simbólico e que demonstra as contradições do episódio. Embora os grupos populares agissem com afinco e interesse, a participação dos poderosos, ao que tudo indica, era ponto fundamental para a manutenção e a continuidade do conflito. ${ }^{76}$

\footnotetext{
${ }^{74}$ A especificidade das clientelas sertanejas não foi mencionada pela historiografia. Maria Verônica Campos, autora que mais detidamente analisou o tema das redes no sertão, qualifica o noroeste mineiro enquanto zona fronteiriça de colonização, o que facultaria à paragem características políticas peculiares. Mas não houve a percepção de que, ali, as redes locais de clientela diferissem, em termos de composição social, daquelas existentes no centro da capitania. CAMPOS, Maria Verônica. Governo de mineiros: "de como meter as minas numa moenda e beber-lhe o caldo dourado", 1693 a 1737. São Paulo, 2002. Tese de Doutorado, História, Faculdade de Filosofia, Letras e Ciências Humanas, Universidade de São Paulo, p. 344-380.

75 ANTT. Edital rebelde assinado por Paulo Barbosa Pereira. Documento sem data. Manuscritos do Brasil, livro 10, fl. 95.

${ }^{76}$ ANASTASIA, Carla. Vassalos rebeldes: violência coletiva nas Minas na primeira metade do
} 
A extensão dos tumultos que, intermitentes, duram de março a outubro de 1736, despejou uma grande quantidade de murmurações. Correram mil notícias, muitas delas falsas, outras duvidosas. Houve boa dose de mistério, de encenação, de mentiras, às vezes alinhavadas pelos próprios funcionários do governador. Decidir entre o real e o forjado é coisa difícil na documentação. Em parte, podese explicar isto recorrendo à lonjura que separava as entranhas do São Francisco da porção mais institucionalizada de Minas. Enquanto nos centros mineradores os boatos chegavam rápida e diretamente ao palácio do general, no agreste, abria-se certa margem de manipulação. A distância bloqueava as comunicações, e o que se sabia em Vila Rica poderia ser facilmente orquestrado nas cartas oficiais que circulavam entre as autoridades. Não obstante os inúmeros espias e confidentes espalhados no sertão, Martinho de Mendonça não hesitou em pedir novas aos passageiros e viandantes que trafegavam do São Francisco a Sabará.

Relevante foi o desempenho discursivo dos clérigos sertanejos. Um dos militares enviados ao São Francisco argumentou que, ali, "os frades e muitos clérigos são a pedra do escândalo, pois eles moveram as águas para esta enxurrada". ${ }^{77} \mathrm{O}$ vigário Antônio Mendes Santiago era tido por autor dos editais rebeldes, veiculados a partir de julho. Mas ele não estivera só: “quase todos os clérigos e frades" agiam como "fomentadores". 78

Comprovando isto, existiram paródias do pai-nosso, tradicional oração cristã, copiadas em manuscritos que circularam durante a revolta. Um dos libelos intitulava-se Padre nosso dos moradores das minas gerais, minas novas dos currais, minas de vários metais, minas do rio das mortes, minas do sabará, fortes minas do serro do frio, minas de prover seu brio, minas de goiases, minas dos topázios, minas do inferno, minas, minas de todo o delírio. Em lugar do "pai" celestial, o documento interpelava o soberano português, rogando-lhe o alívio das agruras sertanejas. A queixa central recaía sobre o quinto, tributo malévolo que o rei intentava cobrar dos vassalos mineiros, à custa de tirania e pecado.

Suplicam ao "senhor soberano" enquanto Padre nosso. As Minas descobriram riquezas, alevantando o monarca às alturas Que estais no céu. Mas o paraíso real era falso, não o fazendo Santificado. O "grande brado destes pobres

século XVIII. Belo Horizonte: Ed. C/ Arte, 1998, p. 80-81.

77 ANTT. Carta de João Bezerra da Silva a Martinho de Mendonça de Pina e de Proença. Paraúna, 27 de agosto de 1736. Manuscritos do Brasil, livro 10, fl. 71.

${ }^{78}$ ANTT. Relação de pessoas envolvidas nos motins. Vila Rica, $1^{\circ}$ de maio de 1737. Manuscritos do Brasil, livro 10, fl. 64-64v. 
moradores" havia sido ignorado, e como isto Seja, sertanejos lembravam sem vontade Vosso nome. Os cobradores do fisco só diziam Venha a nós. E esqueciam dos "muitos direitos" que os súditos possuíam A vosso reino. Para que Seja Feita a Vossa vontade, obrigatório pôr fim à exploração "do suor de tais vassalos" e à "crueldade" com que eram tratados. Assim na terra como nos céus, os quintos deveriam ser revogados, e, daí, "logo ficaremos em paz". O rei tirara o Pão nosso e, por causa disto, eles não pagariam a capitação, mesmo presos a Cada dia. Quisesse fazer o bem, sua Majestade Nos dai hoje tudo "quanto nos tem levado demais". Se os vassalos lhe ofendiam com súplicas, Perdoai-nos. Mas, eles não tinham com que pagar As Nossas dívidas. Trabalhavam pelos matos, com risco de vida, qual "lobisomens", Assim como nós. Pediam por compaixão e quem a negava não Perdoamos. Viviam pobres, sem auxílio, porque ricos não emprestavam Aos nossos. Os quintos assolavam, tornando-os Devedores. Por sua vez, credores pressionavam a que Nos não deixeis de quitar. O povo estava $A$ cair em tentação, cometendo roubos e depravações morais. Ao soberano rogavam, enfim, Livrai-nos de todo o mal, evitando "baixezas", "para que vosso nome em Portugal e em todo mundo tenha luz e como Santo vos adoraremos Amém Jesus" ${ }^{79}$

Outras comunicações também foram utilizadas. O mestre-de-campo João Ferreira Tavares de Gouveia remeteu ao governador alguns exemplares de um edital, "que o povo (ou algum bribante em seu nome) fez publicar nestas partes e o trasladou o dito da sua letra". O militar comentou que "qualquer mulato ou negro que sabe escrever tem por estes desertos confianças para estas e outras tais, sem temor de Deus nem das justiças”. Durante a revolta, os amotinados retiravam das paredes os documentos oficiais, para afixarem seus próprios libelos sediciosos. Na capela do Arraial das Almas haviam sido postos "outros pasquins muito mais indecentes, e vergonhosos, em lugar de uns editais do Exmo. Sr. Gomes Freire de Andrade". ${ }^{80}$

Em 1737, já desbaratados os motins e presos os principais líderes, a situação política da capitania de Minas Gerais nem por isto silenciara. Martinho

\footnotetext{
79 ANTT. Padre-Nosso dos moradores... Manuscritos do Brasil, livro 10, f1. 210. Este documento foi transcrito e analisado por FIGUEIREDO, Luciano. Revoltas, fiscalidade e identidade colonial na América portuguesa: Rio de Janeiro, Bahia e Minas Gerais, 1640-1761. São Paulo, 1996. Tese de Doutorado, História, Faculdade de Filosofia, Letras e Ciências Humanas, Universidade de São Paulo, p. 172-190.

${ }^{80}$ ANTT. Carta de João Ferreira Tavares de Gouveia a Martinho de Mendonça de Pina e de Proença. Arraial de Capela das Almas, sem data. Manuscritos do Brasil, livro 1, fl. 22-22v.
} 
de Mendonça encontrava-se ainda no centro da ladainha pública. O dirigente confessou a Gomes Freire que as atuais diabruras lhe davam "mais cuidado (...) agora que em agosto de 36". Em uma noite de quarta-feira, a 30 de outubro de 1737, na vila do Carmo, um "mulatinho" vagueara a gritar "em vós alta e nas ruas mais públicas": "Viva El Rei, Viva o Povo, e morra Martinho de Mendonça". O brado noturno era idêntico ao que se proclamara no sertão. Suspeitava-se que os poderosos conspirassem, através de cartas e conversas sediciosas. Martinho temia que "movido e alterado uma vez o vulgo não é fácil pôr termos aos seus desatinos". Sabia-se alvo das maledicências:

todo o mundo sabe o entranhável ódio que o vulgo tem à minha pessoa, que reputa causa única de resoluções violentas, e da capitação. V. Exa. não ignora a inimizade que pessoas que tem grande influxo com o Povo, a publicidade com que [não] só murmuravam, mas escarneciam de mim, as indiretas diligências que se tem feito para persuadir ao público que estou na desgraça, e os passos que se tem dado para diminuir o pouco respeito, com públicas desatenções e descortesias.

O funcionário reconhecia que era muito mais "abominado" pelo "Povo miúdo". Na comarca do Rio das Mortes, por exemplo, os poderosos locais não lhe caluniavam, mas, em contrapartida, "se lá correm igualmente estas vozes é coisa do vulgo". ${ }^{81}$ Os pobres lhe alcunharam "algoz do Povo", sob murmúrios insuportavelmente públicos. ${ }^{82}$

Martinho foi considerado único responsável pela capitação. O tributo sugeria boatos múltiplos: "publicou-se que a capitação continuava só por arbítrio meu, que tinham chegado ordens do Rio de Janeiro para cessar, e introduzir fábrica de moedas em Minas". Em seguida, o envio de militares mineiros para a peleja no sul, nos conflitos com os espanhóis, fez os moradores começarem a "espalhar que, naquele caso, devia cessar a capitação, e conceder-lhes moratória às dívidas particulares”. Na opinião do funcionário, o modelo fiscal se fazia detestável não por causa de suas possíveis injustiças, mas porque impedia fraudes. Em certo sentido, a capitação era mesmo útil aos mineiros, diminuindo o montante de suas contribuições; porém, isto pouco importava ao povo, quando este sempre "se move por apreensões mais que por realidades". À plebe das Minas só

\footnotetext{
${ }^{81}$ ANTT. Carta de Martinho de Mendonça de Pina e de Proença a Gomes Freire de Andrade. Vila Rica, $1^{\circ}$ de novembro de 1737. Manuscritos do Brasil, livro 3, fl. 337-39.

${ }^{82}$ Motins do sertão. RAPM, v. 1, 1896, p. 664.
} 
apetecia "novidades e mudanças, sem averiguar se lhe são prejudiciais e assim tomaram tanto corpo estas vozes, que posso afirmar que hoje são poucos os que duvidam da sua certeza". ${ }^{83}$

Também se imputou a ele toda a culpa das devassas contra os contrabandos e moedas falsas. "Como pessoalmente executei prisões e buscas", explicava o fidalgo, "não dei nesta ocasião pequeno motivo a se aumentar o ódio geral, pois era causa comum, para quase todos, o descaminho do quinto." Murmurava-se que, na corte, o rei teria desabonado os procedimentos do interino, retirando-lhe uma mercê. Estas vozes "pouco a pouco iam fazendo impressão no ânimo do povo" ${ }^{84}$

O desfecho de seu mandato é dramático. Acuado, vilipendiado, malquisto, Martinho sofria ameaças de morte e engolia, medroso, sua alimentação caseira, desconfiando de que pudesse estar envenenada. Os povos de Minas não obedeciam a verdades objetivas, e sim a imaginações mirabolantes. Um interino, como ele, não podia manter sob controle "todas estas quimeras, vozes espalhadas, e tudo mais". ${ }^{85}$ Urgia que Gomes Freire de Andrade retornasse à capitania, enquanto legítimo general, "redentor das Minas". Um simples "escudeiro de aldeia" era pessoa desapropriada àquele governo, pois ali "as aparências exteriores de autoridade são o primeiro predicado que se deve buscar". Auréola simbólica devia transmitir-se publicamente por parte do governante, dialogando e convencendo os diversos grupos sociais da capitania, "para que os povos lhe tenham grande respeito, os poderosos lhe obedeçam com menos repugnância e os ministros se persuadam que S. Majestade faz dele justa confiança". ${ }^{86}$

\section{Conclusão}

A década de 1730 reforça algumas temáticas murmurativas já preexistentes na história das Minas, ao passo que lança novos itens discursivos. Especulações sobre o quinto, maledicências a respeito dos governadores e ministros, queixas contra o mau governo foram tópicos retóricos aprofundados durante o período. Ao contrário de dom Lourenço de Almeida, Martinho de Mendonça escapou da acusação de enriquecimento ilícito. Mas, em compensação, foi alvo de vozes que

\footnotetext{
${ }_{83}$ Motins do sertão. RAPM, v. 1, 1896, p. 669.

${ }^{84}$ Motins do sertão. RAPM, v. 1, 1896, p. 649-672, passim.

${ }^{85}$ ANTT. Carta de Martinho de Mendonça de Pina e de Proença a Gomes Freire de Andrade. Vila Rica, 8 de novembro de 1737. Manuscritos do Brasil, livro 3, fl. 342.

${ }^{86}$ Motins do sertão. RAPM, v. 1, 1896, p. 671-72.
} 
lhe imputavam as maiores tiranias, transformando-se em personagem popularmente malquista. Ao mesmo tempo, viu-se inserido em uma recente retórica de insatisfação. A famosa e ainda desconhecida "decadência" da extração aurífera, que marcaria o futuro de Minas Gerais, teve seus primeiros lampejos discursivos a partir de 1713, aparecendo também na década seguinte.$^{87}$ Porém, foi depois dos anos 1730 e, especialmente, com a capitação, que os argumentos desta retórica apresentaram-se com clareza. Considerado o algoz da capitação, o interino herdou a sensível memória da decadência, como o seu primeiro causador. Em 1744, a Câmara de São José puxava o cordão umbilical da crise até as tiranias do funcionário ${ }^{88}$ Alguns anos depois, um anônimo rememorava que, até 1735 , houvera a "bonança", logo substituída pelo braseiro das Minas, "no incêndio em que as pôs o servo e açoite de Deus, Martinho de Mendonça". 89

Outra novidade esteve ligada a um tom mais áspero de argumentação política. Alguns conteúdos dos Furores Sertanejos demonstram a existência, ainda que indireta, de certa animosidade contra a figura real. O pai-nosso rebelde subentende, em alguns trechos, uma crítica que não era mais devotada unicamente aos maus funcionários da monarquia e, sim, à própria pessoa do monarca. O rei benevolente com o abuso de seus representantes, o rei que empobrecia seus vassalos com impostos, o rei que desconhecia o esforço de seus súditos poderia ter seu nome louvado "com pouca vontade”. Seu paraíso, alcançado, assim, tiranicamente, não se fazia "santificado". Durantes as ondas

${ }^{87}$ CAMPOS, Maria Verônica. Governo de mineiros: "de como meter as minas numa moenda e beberlhe o caldo dourado", 1693 a 1737. São Paulo, 2002. Tese de Doutorado, História, Faculdade de Filosofia, Letras e Ciências Humanas, Universidade de São Paulo. Para a autora, a noção de decadência apresentou-se como um recurso retórico desenvolvido, sobretudo, depois que as câmaras perdem a administração direta sobre o recolhimento dos quintos. Também teria contribuído para a sua geração o descrédito da visão contratual, formulada nos primeiros tempos da ocupação e predominante em Minas até 1720 . “(...), a partir de então, a ideia de uma pesada carga tributária e de decadência generalizada de Minas preponderou, ocupando um segundo plano a argumentação de remuneração pelo serviço de descobrir os veios auríferos com uma pequena tributação"; p. 266-68.

${ }^{88}$ Impostos na capitania mineira: clamores e súplicas das câmaras em nome do povo. RAPM, v. 2, p. 287-309, 1897, p. 293.

${ }^{89}$ Notícias do descobrimento das minas de ouro e dos governos políticos nelas havidos. Códice Costa Matoso. Coleção das notícias dos primeiros descobrimentos das minas na América que fez o doutor Caetano da Costa Matoso sendo ouvidor-geral das do Ouro Preto, de que tomou posse em fevereiro de 1749, \& vários papéis. Coordenação geral de Luciano Raposo de Almeida Figueiredo e Maria Verônica Campos. Belo Horizonte: Fundação João Pinheiro, Centro de Estudos Históricos e Culturais, 1999, v. 1, p. 248. 
de violência, também chama a atenção o episódio do rapaz paulista, assassinado por ter proferido um "viva el rei”, em lugar do "viva o povo".

Misteriosamente, percebe-se um acirramento das proposições, um mal-estar extravasado nas histórias. Alguma coisa mudara, após quarenta anos de convivência nas Minas. Os historiadores lançaram suas hipóteses para explicar este sentimento. Maria Verônica Campos frisou o término do ideal corporativo, a derrocada do contrato entre rei e súditos, quando a monarquia não mais precisava negociar com mineiros a troca de serviços prestados. O imaginário da descoberta, à custa de sangue e fazendas, era vocabulário em desuso. ${ }^{90}$ Já para Luciano Raposo de Almeida Figueiredo, o acúmulo de experiências na América estava a criar novos anseios. A elaboração de uma "identidade colonial" forcejava o pacto político para "fronteiras onde colonos fiéis jamais ousaram pisar". 91

Seja como for, as murmurações mineiras acumularam durante quatro décadas preocupações políticas que se repetiam insistentemente. Um discurso oral recorrente, com tópicos já formulados e desenvolvidos, parecia circular entre os moradores, conforme as ocasiões e os grupos sociais envolvidos na conversação. Poderosos, proprietários, grandes comerciantes e mineradores tendiam a articular linguagem essencialmente distinta daquela utilizada pelos despossuídos. À cúpula da sociedade mineira, importava debater temas tais como a metodologia dos impostos, a perda de prerrogativas de mando, as interferências dos agentes governamentais, os problemas ligados a contratos e licenças comerciais. Ao povo miúdo, por outro lado, eram especialmente sensíveis o enriquecimento ilícito dos funcionários, a cobrança desigual de taxas e tributos, o monopólio sobre produtos de primeira necessidade, os abusos de justiça cometidos por ministros. Óbvio, estes assuntos não se dialogavam de forma estanque, nem respeitavam estritos limites de classe. Um boato sobre o quinto, por exemplo, podia congregar línguas entre a elite e os populares, simultaneamente. Mas, é certo, existiam filtros sociais. Quando o conde de Assumar recebeu o segundo memorial rebelde, durante a revolta de Vila Rica, imediatamente intuiu que, ali,

\footnotetext{
${ }^{90}$ CAMPOS, Maria Verônica. Governo de mineiros: "de como meter as minas numa moenda e beber-lhe o caldo dourado", 1693 a 1737. São Paulo, 2002. Tese de Doutorado, História, Faculdade de Filosofia, Letras e Ciências Humanas, Universidade de São Paulo, p. 381-418.

${ }^{91}$ FIGUEIREDO, Luciano Raposo de Almeida. Furores sertanejos na América portuguesa: rebelião e cultura política no sertão do Rio São Francisco, Minas Gerais - 1736. Revista Oceanos, n. 40 "Fronteiras do Brasil Colonial". Lisboa: Comissão Nacional para as Comemorações dos Descobrimentos Portugueses, dezembro de 1999, p. 144.
} 
questões populares haviam sido misturadas às reivindicações dos poderosos. As vozes também possuíam filiação e origem social e todos os governadores de Minas perceberam isto. ${ }^{92}$

As murmurações refletiam as contradições e os arranjos políticos do Antigo Regime. Redes de clientela, hierarquia estamental, desníveis simbólicos, diferenciações de riqueza e condição influenciavam fortemente a divulgação oral. Decerto, os próprios boatos funcionam como uma rede, através da qual as informações eram selecionadas pelos membros dirigentes do bando. Definir qual e que tipo de notícia deveria tornar-se pública possuía importância fundamental no jogo político da capitania. E, neste sentido, as relações de clientela concediam recurso aos poderosos. Através de seus sequazes, escravos, clientes, agregados ou simples amigos, os potentados poderiam veicular vozes públicas, escolhendo conteúdos e temas para o diálogo da população.

No entanto, linguagens ditadas não se repetem uniformemente por todas as bocas. Eram relatos orais, que se reelaboravam no decurso do tempo e nas falas das pessoas. Quem conta um conto aumenta um ponto. Na história, o provérbio significa que a linguagem oral será sempre um fenômeno individual, mesmo quando comum à sociedade. Cada comunicador recebe e transmite mensagens conforme suas preocupações particulares e os limites de seu entendimento. Murmúrios com um conteúdo inicial certamente chegavam modificados à outra ponta da sociedade, acumulando camadas discursivas variadas, que só aparentemente eram a soma do todo. $\mathrm{O}$ mesmo boato podia justapor significados contraditórios entre si. A suspeita de levante escravo, em 1719, por exemplo, alimentou temores na população branca, mas também deu mote a um maior controle do governo sobre os escravos, o braço armado dos potentados. De um lado, a revolta, de outro, a conservação.

A trajetória de uma notícia que, da obscuridade, emerge ao público colonial traz em si conflitos latentes. Autoridades cuidaram em silenciar boatos que fossem prejudiciais à tranquilidade política. Suas comunicações corriam sob segredo, evitando divulgar novidades, cujo conteúdo causasse alarme. Se não conseguissem êxito em abafar uma voz, quase sempre evitavam respondê-la abertamente. Conforme postulara em 1718 o conde de Assumar, quando se via

${ }_{92}$ GASPAR, Tarcísio de Souza. Palavras no chão: murmurações e vozes em Minas Gerais no século XVIII. Niterói, 2008. Dissertação de Mestrado, História, Programa de Pós-Graduação em História, Universidade Federal Fluminense, p. 105-121. 
às voltas com os boatos veiculados nos motins da Barra do Rio das Velhas, dar "pública satisfação" era o mesmo que demonstrar "público receio". ${ }^{93}$ Mas, caso houvesse situação de perigo potencial, não hesitaram intervir no debate, lançando editais, desmentindo boatos, corrigindo informações. ${ }^{94}$

As vozes eram também insistentes. Não se curvam ante a repressão nem mesmo quando desmentidas. Para Martinho de Mendonça a imaginação do vulgo extrapolava qualquer impulso racional ou coerente. Fantasias eram tidas por realidades, e estas, por fantasias. Nada freava o desengano da boataria. Porém, embora pautadas pela irrealidade, as murmurações tinham importância, não em si, mas pelo que representavam. Quando um mulatinho, na Vila do Carmo, prognosticou a morte do funcionário, no fato havia mais que trivialidade. E veio o diagnóstico: "estas vozes proferidas no Carmo em si são nada, mas são sinais de muito". ${ }^{95}$

Recebido: março/2009 - Aprovado: fevereiro/2010.

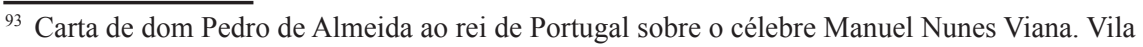
do Carmo, 8 de janeiro de 1719. Cartas do conde de Assumar ao rei de Portugal. RAPM, v. 1, 1896, p. 251-266.

${ }^{94}$ GASPAR, Tarcísio de Souza. Palavras no chão: murmurações e vozes em Minas Gerais no século XVIII. Niterói, 2008. Dissertação de Mestrado, História, Programa de Pós-Graduação em História, Universidade Federal Fluminense.

${ }^{5}$ ANTT. Carta de Martinho de Mendonça de Pina e de Proença a Gomes Freire de Andrade. Vila Rica, $1^{\circ}$ de novembro de 1737. Manuscritos do Brasil, livro 3, fl. 337-39. 